\title{
Professional Competence of an Archivist: Changes that Can Be Expected
}

\author{
Magdalena MAROSZ, Ph.D. \\ Archiwum Narodowe w Krakowie, ul. Sienna 1630-960 Kraków, Poland \\ e-mail:mmarosz@ank.gov.pl
}

Professional Competence of an Archivist: Changes that Can Be Expected

\begin{abstract}
Over the $21^{\text {st }}$ century, the model of professional competence of the archivist will certainly be changing and evolving. Competence, namely is the combination of knowledge and skills which enable the archivist to carry out the assigned tasks efficiently and effectively. These tasks, expected in the perspective of several decades are not quite possible to be predicted today. Undoubtedly now, and in the future even more, we should focus on training the present archivists and educating the future ones in the field of information management, data processing and secure storage of widely understood electronic documentation. So, are we going to witness a gradual evolution of the profession of an archivist towards the information manager, info broker, or a specialist in modern technology? Judging by the changes in the study programs for future archivists, it is highly probable. For the time being, these changes are being introduced quite slowly, at individual universities, but still, they determine a certain direction in education. We should also consider the methodology and standards of dealing with archival resources and the needs in this field, resulting from the changes which are happening now, and the expected ones, caused by the emergence of new techniques and technologies.
\end{abstract}

Key words: archival training, archival education, professional competence, info brokering

La competenza professionale dell'archivista: cambiamenti che si possono ipotizzare

\section{SINTESI}

Nel corso del XXI secolo, il modello della competenza professionale dell'archivista andrà certamente cambiando ed evolvendo. Competenza; ossia la combinazione di conoscenze e competenze che consentono all'archivista di svolgere i compiti assegnati in modo efficiente ed efficace. Queste attività, ipotizzabili in una prospettiva di diversi decenni, non sono oggi ancora abbastanza prevedibili. Senza dubbio ora, ed in futuro ancora di più, dovremo concentrarci sulla formazione degli archivisti presenti ed professionalizzare quelli futuri nel campo della gestione delle informazioni, dell'elaborazione dei dati e della memorizzazione sicura di documentazione elettronica. Allora, vedremo una graduale evoluzione della professione di un archivista verso la gestione di informazioni, di intermediario di informazioni o di specialista della tecnologia moderna? A giudicare dai cambiamenti nei programmi di studio per futuri archivisti, è altamente probabile. Per il momento, questi cambiamenti vengono introdotti abbastanza lentamente; nelle singole università, ma essi determinano ancora una certa direzione nel campo dell'istruzione. Dovremmo anche considerare la metodologia e gli standard di gestione delle risorse archivistiche, e le esigenze in questo campo derivanti dai cambiamenti che stanno avvenendo in questo momento, e quelli previsti causati dall'emergere di nuove tecniche e tecnologie.

Parole chiave: formazione archivistica, competenza professionale, intermediazione dell'informazione

Strokovna kompetenca arhivista: spremembe, ki jih je mogoče pričakovati

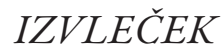

V 21. stoletju se bo model strokovne usposobljenosti arhivista zagotovo spreminjal in razvijal. Kompetence so kombinacija znanja in spretnosti, ki arhivistu omogočajo učinkovito izvajanje dodeljenih nalog. Teh nalog, pričakovanih v perspektivi več desetletij, danes ni mogoče predvideti. Zdaj, in še bolj v prihodnosti, bi se morali osredotočiti na usposabljanje sedanjih arhivistov in izobraževanje prihodnjih na področju upravljanja informacij, obdelave podatkov in varnega shranjevanja elektronske dokumentacije. Ali bomo torej priča postopnemu razvoju poklica arhivista v smeri informacijskega menedžerja, informacijskega posrednika ali strokovnjaka za sodobno tehnologijo? Sodeč po spremembah v študijskih programih za prihodnje arhiviste je to zelo verjetno. Te spremembe se zaen- 
krat uvajajo na posameznih univerzah precej počasi, vendar še vedno določajo določeno smer v izobraževanju. Upoštevati moramo tudi metodologijo in standarde ravnanja $\mathrm{z}$ arhivskimi viri in potrebami na tem področju, ki izhajajo iz sprememb, ki se dogajajo zdaj, in pričakovanih, ki jih povzroča nastanek novih tehnik in tehnologij.

Ključne besede: arhivsko izobraževanje, arhivsko izobraževanje, strokovna usposobljenost, informacijsko posredovanje

Kompetencje zawodowe archiwisty: jakich zmian możemy się spodziewać

\section{ABSTRAKT}

Z pewnością na przestrzeni XXI wieku model kompetencji zawodowych archiwisty będzie się zmieniał i ewoluował. Kompetencji, czyli połączenia wiedzy i umiejętności pozwalających sprawnie i skutecznie realizować powierzone zadania. I te spodziewane zadania w kilkudziesięcioletniej perspektywie czasowej nie do końca są dziś możliwe do przewidzenia. Niewątpliwie należy już teraz, a w przyszłości coraz bardziej, położyć nacisk na szkolenie obecnych i kształcenie przyszłych archiwistów w zakresie zarządzania informacją, przetwarzania danych, czy bezpiecznego przechowywania szeroko rozumianej dokumentacji elektronicznej. A więc czy czeka nas stopniowe ewoluowanie zawodu archiwisty w kierunku zarządcy zapisami informacyjnymi, infobrokera, czy specjalisty z zakresu nowoczesnych technologii? Sądząc choćby po zmianach w programach studiów na kierunkach kształcących przyszłych archiwistów, jest to wysoce prawdopodobne. Zmianach wprawdzie wprowadzanych na razie powoli, na pojedynczych uczelniach, ale jednak wyznaczających pewien kierunek kształcenia. Trzeba także zastanowić się nad metodyką i standardami opracowania zasobu archiwalnego oraz potrzebami w tym zakresie, wynikającymi z zachodzących i spodziewanych zmian będących konsekwencją pojawiania się nowych technik i technologii.

Słowa kluczowe: szkolenie archiwistów, edukacja archiwalna, kompetencje zawodowe, infobrokering

Training and education of archivists in the $21^{\text {st }}$ century - these issues are both important and not easy to determine precisely as for the subject matter. In fact, we will learn only in the second half of the century whether the training of the present and the education of the future archivists in the first half of the $21^{\text {st }}$ century was good and effective. Are we able to predict now how the tasks and the role of the archivist will change in several decades? At such pace and quality of change, the dynamics of the development of new techniques and technologies (especially information and communication ones) and, consequently, the emergence of new information and document carriers, it is doubtful if one can fully responsibly take up such a task. Of course, we can predict the direction quite accurately, but we are not able to determine the details.

At the turn of the $20^{\text {th }}$ century, it was certainly easier to anticipate the development of the archival field in the then coming century, but even then the prediction was not surprise-free. Who could have foreseen in the era of the paper document that the end of the century would bring such revolutionary changes as the appearance and rapid development of the electronic document? I do not think there existed such visionaries at the beginning of the century. It was certainly not anticipated then, either, how the development of photography, film or sound recordings will continue - of these maybe not new, but certainly innovative techniques of image and sound recording. Was it expected that the development of photographic and audiovisual technology would determine such mass production of this kind of documentation? Documentation created not only for entertainment but also being an extremely important historical source.

Thus, since we cannot predict which surprises and new challenges might be confronted by archival science in the coming 83 years, let's concentrate on what we know today, on the predictable directions of development.

So what about the current model of archivist education? No one can doubt that we should think about changes. In what direction - it also seems clear, though certainly the universities educating archivists will face various dilemmas while designing curricula.

Let's take a look at what is offered and how students are encouraged to take up archival studies broadened by issues related to information search or knowledge management at two Polish universities. 
Magdalena MAROSZ: Professional Competence of an Archivist: Changes that Can Be Expected, 149-153

The Pedagogical University of Krakow in the subject of Info broking, Documentation Management and Archival Science (note the order) guarantees students will gain the following skills and knowledge:

- knowledge of various sources of information: traditional and electronic ones;

- skills necessary to set up and run one's own info broking company;

- knowledge and skills in the field of organization and management of electronic and traditional documentation as well as information resources in the contemporary world;

- ability to function within office procedures (basic issues of work organization, history of administration, office systems, administrative procedures, access to information and protection of data);

- preparation to work as an archivist and info broker, at government and local government offices, and in institutions gathering and processing data and documentation in administration, companies, science sector, culture and education ${ }^{1}$.

The Maria Curie-Skłodowska University in Lublin, in the subject of Archival Science and Modern Information Technology Management, offers:

- archival specialisation, whose graduates are prepared to work in all types of archives in collection, storage, studying and sharing of archival resources, they also obtain qualifications of a specialist in document management,

- the specialisation of modern document management, which mainly prepares students for the profession of records manager and gives the graduates the knowledge, skills and basics for designing, creating and operating Records Management systems which can cover both electronic and paper documents, complies with the norm of ISO 15489, which has been in force in Poland since 2006.

- the specialisation of IT office specialist prepares the students to operate the latest IT systems and programmes used in offices, registries and archives; its graduate gains competences in document and information management in both traditional and electronic form. Among the subjects of the new specialiation there are also, among others: The basics of the database, Office and Archival IT, Enterprise Content Management Software (ECM), and Data Mining².

In addition, the Pedagogical University of Krakow offers postgraduate studies, so the ones intended for graduates of higher education institutions who wish to further their education in Document Management, Info broking and Archival Science (again, note the order):

- the studies prepare for office work, as well as for the profession of an archivist and info broker, that is a person who is commissioned to search for, analyse, select, process and transfer information;

- enable to gain skills of the use of office procedures (work organization, history of administration, development of office systems, administrative proceedings, data protection);

- prepare for work as an archivist and info broker, in an office position in the governmental and self-government administration offices and in institutions collecting and processing data and documentation in the administration, companies, science sector, culture and education;

- the studies are intended for persons wishing to acquire qualifications in the field of the latest electronic document management systems, implemented in public administration within the process of computerization of the state ${ }^{3}$.

Also in the curricula of the studies in the field of archival science and document management carried out at many Polish universities, historical subjects and archival theory cease to dominate, leaving the field for the knowledge of management of the archives, documentation management (also with the use of electronic techniques), issues related to the electronic document, digitation of archival collections as well as modern technologies, both those directly applicable in the work of an archivist and those in the field of

1. cf.: http://www.up.krakow.pl/studia/studia-i-stopnia/402-infobrokerstwo-zarzadzanie-dokumentacja-i-archiwistyka-istopnia-2016-2017; (accessed on 27.03.2017).

2. cf.: http://www.umcs.pl/pl/wyszukiwarka-studiow,118, archiwistyka-i-nowoczesne-zarzadzanie-zapisami-informacyjnymi,6740.chtm (accessed on 27.03.2017).

3. cf.: http://www.podyplomowe.up.krakow.pl/window.php?page=informator\&run=det\&id=854

(accessed on 27.03.2017). 
search for information or knowledge management. So combining archival science with history is not so obvious now; in the curricula there appear options of combining archival science with scientific information or library science, and also independent subjects such as archival science and document management appear. (see Marosz, 2014).

It should be assumed that in the educational programme the model of educating and training of archivists is adapted primarily to the needs of the archives, so any changes in the model of education occur with the evolving needs of archival institutions. The collection, storage, analysis and sharing of archival collections in the world of the internet and, in general, technological changes which are getting more and more also into the archives, are beginning to take on new meanings. Electronic documents or digitalisation of traditional documents offer ample opportunities of virtually unlimited access to archival materials. While access to the information one seeks is faster and easier, one can sometimes get lost in the magnitude of emerging data.

So, in this situation, will the profession of info broker, specializing in the search for specific information made available on the net by the archives, be needed and helpful for those who find such a search too difficult or too time consuming? Because there is no doubt that information resources growing more and more rapidly on the net are becoming increasingly difficult for the people with no experience and skills in using them, so also in the search for information. And here there appear opportunities for the activity of information brokers (info brokers), that is the people who offer their services in finding and providing specific information. They undertake to verify it, guarantee the accuracy and quality of the information found in the commissioned research, and also assist, if necessary, in the understanding of the information obtained and its sources (Szczepańska, 2002).

It is worth mentioning that in 1987 an organization called The Association of Independent Information Professionals was established, which conducts, among others, activities aimed at setting standards for the operation of information brokers (see Code).

Until recently, studies in the field of widely understood information management were available only in the library science subjects or in marketing and management studies. They now appear in archival subjects, which enables us to assume that they are supposed to educate people specializing in the search for information, or in the management of information resources and the knowledge from the field of archival science. The area which in this case should be defined as source materials (also, or maybe in this situation - primarily - available in digital form) and information extracted from them, as well as archival databases. And this is here I would see the basic area of activity for professionals in the field of 'archival info broker".

However, when we reflect on who the info broker is and what the essence of this profession according to today's definitions is, an unexpected reflexion comes. The necessary conditions for being an info broker are: being an intermediary between information resources and the people and organizations that need information; selling information services (not information as such); possessing appropriate competence; being guided by professional ethics; making use of only legitimate sources of information; being independent; offering services for a fee (Code, see Cisek, 2013). And here the question arises: how to reconcile being independent, that is running one's own business and offering services, with the work of an archivist employed on a permanent basis in an archival institution, an institution which on principle provides services in the field of access to information contained in the archives and in specialized databases free of charge? It seems that the authors of study programmes offering preparation for this profession at the studies which combine info brokering, document management and archival science did not address to such a question. Although, judging by the great interest among students (both undergraduate and postgraduate) in this field, it meets the needs well and fills the niche in the offer of education and training of archivists. It is therefore likely that it will be necessary to redefine this concept for the needs of education of archivists which prepares them to work in the specialisation of info broker.

On the other hand, the combination of archival studies and education, with the training in the area of management of IT records may also, in the future, provide archivists who will also be specialists with competence in the application and use of modern information and communication technology in various forms of activity related to the functioning of the archives. Also professionals possessing competence in the area of comprehensive search for information in databases and on the Internet, as well as creating and sharing specialized information databases. And here maybe we would find a golden means to 
combine the qualifications of an archivist, info broker (assuming the abovementioned changes in the definition of this profession) and specialist in information management.

\section{References}

Cisek, Sabina (2013). Broker informacji w spoteczeństwie wiedzy. Available at: http://eprints.rclis.org/10880/1/ Cisek_broker_informacji_istota.pdf (accessed on 07.03.2017).

Code of Ethical Business Practice: Association of Independent Information Professionals. Available on: http://aiip. org/about/professional-standards (accessed on 10.03.2017).

Mamczak-Gadkowska, Irena (2009). Kierunki zmian w ksztatceniu archiwistów na przetomie XX I XXI wieku, Res Historica 28, pp. 9-19.

Marosz, Magdalena (2014). Archival education, ATLANTI, 24/2, pp 141-147.

Szczepańska, Barbara (2002). Broker informacji - zawód z przysztósią czy zawód z przysztości, Biuletyn EBIB, 11 (40). Available at: http://www.ebeb.pl/2002/40/szczepanska.php (accessed on 07.03.2017).

Thomassen, Theo (2001). Modelling and re-modelling archival education and training. Available at: http://www. ica-sae.org/mrconfpaper1.html (accessed on 24.03.2017).

\section{SUMMARY}

Technological progress, going on continuously and, what is more, at an ever-increasing pace, necessitates the modernization of curricula at all levels of archival education. Not only undergraduate or post-graduate study programmes undergo adequate changes, but more and more often other offers of training appear, such as specialized courses or training courses, also organized by archives and led by archivists. The so-called Bologna system, widely introduced in universities, can also contribute positively to the education of archivists, allowing for the combination of archival science with other disciplines at various levels of education (bachelor, masters, and doctoral studies). It should also be remembered that the model of broadly understood training of archivist has a direct connection, or even arises from the needs of archival institutions, first of all from their need of well and comprehensively educated staff. But archival institutions are also interested in direct involvement in the process of training of archivists, providing them with practical knowledge, apart from theory mostly included in educational programmes. An equally important factor affecting the scope of education and training of archivists is the social need - hence the link between archival science and info broking or multidimensional information management in the archival education offered for archivists (both in postgraduate and postgraduate studies). In the training of archivists, the scope, subject matter of the curricula and the direction of their evolution should be closely connected with the definition of the archivist's competence which is required today and will be required in the future. As stated by Theo Thomasen during his presentation at the First European Conference for Archival Educators and Trainers (Thomasen, 2001), in archival education, which is vocational education, four main directions of change may be identified: expansion, innovation, integration and professionalism. The change of the scope of the archivist's responsibilities entails the need to expand his competence, which in turn results in the necessity of expansion and evolution of educational programmes. Innovation in archivist training is the result of the development of technology, especially of information technology. Innovative training is intended to facilitate adaptation to the changing working conditions. It is assumed that the best learning outcomes are achieved through integral education, so the one combining areas of different fields of study, and also linking science or theory to work or practice. Professional staff can be educated only by professional teachers. Thus, in order to train professional archivists, we also need professional lecturers, equipped not only with a wide range of knowledge in various, constantly new, areas, but also with a great teaching skills, which together should facilitate their transition into a new model of education. A model based on creative problem-solving and task-performing.

Typology: 1.04 Professional Article

Submitting date: 12.04 .2017

Acceptance date: 05.05.2017 